\title{
ADMINISTRASI KELOMPOK TANI DI KECAMATAN TOMOHON UTARA, KOTA TOMOHON
}

\author{
Daisy Sumilat \\ Grace A. J. Rumagit \\ Welson M. Wangke
}

\begin{abstract}
The study aims to determine the completeness of the administration of farmers' groups in North Tomohon Sub-district, Tomohon City. The research was conducted from July to September 2016. The data were used primary data. Sampling method on three (3) groups of farmers in the district of North Tomohon is done by purposive sampling. The variables in this study are the characteristics of the board of farmer group organizations (Chairman, Secretary, and Treasurer), characteristics of the farmer group (the name of the farmer groups, year of farmer groups established, and the number of members of farmer groups) and administrative group books. The administration books have two main parts: the books of administrative activities and the books of administration finance. The analysis used for variable administrative and financial administration which each answer is associated with a form of the statement expressed by the words that Good was given Score: 3, Less Good granted Score: 2 and No Good granted Score: 1. The results of this research farmer group that is located relatively far from BP $3 K$ Office have good administrative requirements compared to the farmer group that is located very close to BP3K Offuce. That's because a group of farmers near BP3K office has motivation to get funding and the lack of cooperation among the board members in addition to the lack of visitation held by agriculutere extension staf, while the farmer groups that located far from BP3K Office has established with motivated to increase the welfare of members of farmers, the board members has good cooperation and good management. It is also the group always get the attention of the agriculutre extension staf by holding regular visitation to the farmer groups and therefore contributes positively to the administrative requirements for farmers' groups
\end{abstract}

Keywords: administration, farmers group, North Tomohon Sub-district, Tomohon City

Penelitian bertujuan untuk mengetahui kelengkapan administrasi kelompok tani di Kecamatan Tomohon Utara, Kota Tomohon. Penelitian dilaksanakan pada bulan Juli sampai September 2016. Penelitian ini menggunakan data primer. Metode pengambilan sampel pada 3 (tiga) kelompok tani yang ada di Kecamatan Tomohon Utara Kota Tomohon dilakukan dengan cara sengaja (Purposive Sampling). Variabel dalam penelitian ini adalah karakteristik organisasi kelompok tani (Ketua, Sekretaris, Bendahara), karakteristik kelompok tani yaitu nama kelompok tani, tahun berdiri kelompok tani, jumlah anggota kelompok tani dan kelengkapan buku administrasi kelompok tani. Buku administrasi dibedakan dalam 2 kelompok besar yaitu buku administrasi kegiatan dan buku administrasi keuangan. Analisis yang digunakan untuk variabel buku administrasi kegiatan dan buku administrasi keuangan yaitu setiap jawaban dihubungkan dengan bentuk pernyataan yang diungkapkan dengan kata-kata yaitu Baik diberikan Skor: 3, Kurang Baik diberikan Skor: 2 dan Tidak Baik diberikan Skor: 1. Dari hasil penelitian yang didapatkan, kelompok tani yang letaknya relatif jauh dari Kantor BP3K memiliki kelengkapan administrasi yang baik dibandingkan dengan kelompok tani yang letaknya sangat dekat dengan BP3K. Hal itu disebabkan karena kelompok tani yang dekat dengan Kantor BP3K mempunyai motivasi hanya untuk mendapatkan bantuan dan kurangnya kerja sama antara sesama pengurus selain itu kurangnya perkunjungan yang diadakan oleh penyuluh pada kelompok tani yang dekat dengan BP3K, sedangkan pada kelompok tani yang jauh dari Kantor BP3K memiliki motivasi untuk mensejahterakan anggota kelompok tani dengan kerja sama antar pengurus dan manajemen yang baik, juga selalu mendapatkan perhatian dari penyuluh dengan mengadakan perkunjungan secara rutin kepada kelompok tani sehingga berpengaruh terhadap kelengkapan administrasi kelompok tani tersebut.

Kata kunci: Administrasi, Kelompok Tani, Kecamatan Tomohon Utara, Kota Tomohon 


\section{PENDAHULUAN}

Semua usaha pertanian pada dasarnya adalah kegiatan ekonomi sehingga memerlukan dasar-dasar pengetahuan yang sama akan pengelolaan tempat usaha, pemilihan benih/bibit, metode budidaya, pengumpulan hasil, distribusi produk, pengolahan, pengemasan produk, dan pemasaran. Apabila seorang petani memandang semua aspek ini dengan pertimbangan efisiensi untuk mencapai keuntungan maksimal maka harus melakukan pertanian intensif (intensive farming). Usaha pertanian yang dipandang dengan cara ini dikenal sebagai agribisnis. Program dan kebijakan yang mengarahkan usaha pertanian ke cara pandang demikian dikenal sebagai intensifikasi. Karena pertanian industrial selalu menerapkan pertanian intensif, keduanya sering kali disamakan. Sisi yang berseberangan dengan pertanian industrial adalah pertanian berkelanjutan (sustainable agriculture) (Departemen Pertanian, 2007).

Kondisi sosial budaya petani merupakan masalah utama dalam fungsi sektor pertanian di dalam pembangunan nasional dan kemampuan sektor tersebut untuk bersaing pada abad yang akan datang. Berdasarkan data statistik yang ada, saat ini sekitar $75 \%$ penduduk Indonesia tinggal di wilayah pedesaan. Lebih dari $54 \%$ diantaranya menggantungkan hidup pada sektor pertanian. Perbedaan tersebut berkaitan erat dengan produktifitas para petani Indonesia, yang tidak dapat dilepaskan dari berbagai factor antara lain, luas lahan yang dimiliki dan kebijakan pemerintah dalam hal pemberian insentif kepada petani (Oudejans, 2006).

Slamet (2000) mengatakan bahwa petani disebut petani 'asli' apabila memiliki tanah sendiri, bukan sekedar penggarap maupun penyewa. Secara konseptual, tanah merupakan bagian yang tidak dapat dipisahkan dari kehidupan seorang petani. Tanah bukan hanya sebagai alat produksi utama petani, melainkan sebagai alat produksi mutlak dimiliki seorang petani. Implikasinya, petani yang tidak memiliki tanah sendiri tidak dianggap sebagai petani sejati atau asli. Implikasi politisnya, petani mutlak dan mempertahankan dan menjaga hak kepemilikannya atas tanah (Sadikin, 2001).
Nuryanti dan Swastika (2011) menjelaskan bahwa secara umum, kelompok tani dibentuk untuk memecahkan permasalahan yang dihadapi kelompok tani yang tidak bisa diatasi secara individu, kelompok tani dapat dibentuk secara swadaya maupun atas dasar kepentingan kebijakan dari pemerintah melalui Dinas Pertanian, untuk itulah petani perlu berkelompok.

Petani sangat sering dihadapkan dengan sosialisasi dan penyuluh pertanian, yang didalamnya penyuluh memenuhi administrasi. Administrasi yang dimaksud adalah administrasi penyuluhan agar kegiatan sosialisasi berjalan dengan lancar atau terstruktur. Kelembagaan penyuluhan pertanian merupakan salah satu wadah organisasi yang terdapat dalam Dinas Pertanian. Kelembagaan pertanian menyesuaikan dengan perubahanperubahan yang ada. Organisasi digunakan sebagai tempat atau wadah dimana orang-orang berkumpul, bekerjasama secara rasional dan sistematis, terencana, terorganisasi, terpimpin dan terkendali, dalam memanfaatkan sumber daya (uang, material, mesin, metode, lingkungan), sarana-prasarana, data, dan lain sebagainya yang digunakan secara efisien dan efektif untuk mencapai tujuan organisasi (Ode, 2014)

Dalam perangkat administrasi dibedakan menjadi dua bagian pokok yaitu: administrasi kegiatan dan administrasi keuangan. Dalam administrasi kegiatan, segala catatan yang dilakukan oleh kelompok berkaitan dengan kegiatan kelompok diluar urusan keuangan. Sedangkan administrasi keuangan, segala catatan yang khusus berkaitan dengan keuangan kelompok (Kementrian Pertanian, 2014).

Kota Tomohon sebagian besar merupakan masyarakat petani. Menurut data BP4K Kota Tomohon memiliki 476 kelompok tani, Kecamatan Tomohon Utara sendiri mempunyai 154 kelompok tani dan yang terdaftar di BP3K masing-masing kelurahan terdapat 1 orang PPL. Ada sekitar $70 \%$ kelompok tani yang lebih aktif pada saat ada bantuan, dan hanya $30 \%$ yang terus berjalan walaupun tanpa adanya bantuan. 
Kelengkapan administrasi Kelompok tani yang letaknya dekat dengan BP3K sudah pasti jauh lebih baik dari kelompok tani yang letaknya jauh dari BP3K. Karena kelompok tani yang letaknya dekat dengan BP3K lebih mudah mendapatkan informasi, sosialisasi dan penyuluhan pertanian dibandingkan dengan kelompok tani yang jauh dari BP3K.

Kelompok tani Susuripen berada di kelurahan Wailan dan kelompok tani Sinambeey Mujair yang berada di kelurahan Kinilow merupakan kelompok tani yang letaknya jauh dari BP3K, sedangkan kelompok tani yang letaknya dekat dengan BP3K yaitu kelompok tani Rewoh Indah yang berada di Kakaskasen Dua. Menjadi hal yang sangat menarik untuk diteliti adalah administrasi kegiatan maupun keuangan kelompok tani di Kecamatan Tomohon Utara yang diukur dari atau diwakili oleh tiga kelompok tani yang letaknya jauh dari BP3K dan dekat dengan BP3K.

\section{Perumusan Masalah}

Berdasarkan latar belakang, yang menjadi perumusan masalah dalam penelitian ini ialah bagaimana kelengkapan administrasi kelompok tani di Kecamatan Tomohon Utara Kota Tomohon?

\section{Tujuan Penelitian}

Penelitian ini bertujuan untuk mengetahui kelengkapan administrasi kelompok tani di Kecamatan Tomohon Utara Kota Tomohon.

\section{Manfaat Penelitian}

Penelitian ini diharapkan bermanfaat bagi upaya meningkatkan administrasi kelompok tani, khususnya di Kecamatan Tomohon Utara Kota Tomohon dan memberikan informasi bagi pihak yang membutuhkan informasi sehubungan dengan penelitian ini.

\section{METODOLOGI PENELITIAN}

\section{Waktu dan Lokasi Penelitian}

Penelitian ini berlangsung selama 3 (tiga) bulan yaitu mulai bulan Juli sampai September 2016, di Kecamatan Tomohon Utara Kota Tomohon.

\section{Metode Pengambilan Sampel}

Metode pengambilan sampel pada 3 (tiga) kelompok tani yang ada di Kecamatan Tomohon Utara Kota Tomohon dilakukan dengan cara sengaja (Purposive Sampling), pada 2 (dua) kelompok tani yang berlokasi jauh dengan kantor Balai Penyuluhan Pertanian Perikanan dan Kehutanan yaitu Kelompok tani Susuripen berada di Kelurahan Wailan dan kelompok tani Sinambey Mujair yang berada di Kelurahan Kinilow, dan 1 (satu) kelompok tani yang letaknya dekat dengan BP3K yaitu kelompok tani Rewoh Indah yang berada di Kakaskasen Dua. Kelompok tani yang dekat dengan BP3K lebih mudah mendapatkan informasi dan sosialisasi dari penyuluh dari pada kelompok tani yang jauh dari BP3K.

\section{Metode Pengumpulan Data}

Metode yang digunakan dalam penelitian ini, yaitu metode survey. Data yang digunakan data primer yang diperoleh dari wawancara langsung dengan anggota kelompok tani (Ketua, Sekretaris, Bendahara) berdasarkan daftar pertanyaan yang disiapkan.

\section{Konsep dan Pengukuran Variabel}

Variabel dalam penelitian ini adalah :

1. Karakteristik Organisasi Kelompok Tani (Ketua, Sekretaris, Bendahara)

2. Karakteristik Kelompok Tani : nama kelompok tani, tahun berdiri kelompok tani, jumlah anggota kelompok tani dan administrasi kelompok tani dilihat dari 2 bagian pokok administrasi, yaitu:

1) Administrasi Kegiatan

a. Buku induk anggota: diisi pada saat petani pertama kali mendaftar sebagai anggota kelompok

b. Buku tamu: diisi setiap kali kedatangan tamu

c. Buku notulen rapat: diisi setiap ada kegiatan rapat

d. Buku kegiatan kelompok: diisi ketika ada kegiatan yang dibuat

e. Buku produktivitas dan Hasil Produksi: diisi setiap kali ambil hasil dan akhir jumlah hasil yang dijual

f. Buku agenda surat masuk dan surat keluar : diisi pada saat ada surat-surat dari luar yang masuk dan keluar (proposal, dll). 
g. Buku ekspedisi : diisi pada saat pengiriman ada barang kepada anggota dari pihak luar sebagai bukti yang berupa dokumen maupun surat

h. Buku kepemilikan sarana/prasarana anggota: diisi setiap ada bantuan alat yang diterima oleh kelompok tani

i. Buku luas lahan garapan: dokumen tertulis yang berisi tentang luas areal lahan garapan anggota kelompok

j. Buku pengurus: diisi setiap periode kepengurusan yang disepakati, yang didalamnya tertulis biodata petani yang menjadi pengurus.

k. Buku daftar hadir: diisi setiap kali ada kegiatan yang dilakukan kelompok tani.

Yang dapat diukur lewat:

- Baik (3) = buku ada, di isi lengkap dan benar

- Kurang Baik (2) = buku ada tapi buku tidak diisi dengan lengkap.

- Tidak Baik (1) = buku tidak ada.

2) Administrasi Keuangan

a. Buku kas: diisi setiap kali ada kegiatan kelompok yang menyangkut keluar masuknya keuangan kelompok.

b. Buku iuran anggota: diisi pada saat masuknya iuran dalam bentuk uang tunai kedalam kas kelompok

c. Buku tabungan anggota: diisi pada saat masuknya tabungan dalam bentuk uang tunai kedalam kas kelompok

d. Buku inventaris: diisi pada saat ada barang, sarana dan prasarana pertanian seperti alatalat mesin yang berasal dari pembelian yang dilakukan kelompok tani maupun dari bantuan pemerintah.

e. Buku penjualan: diisi pada saat kegiatan penjualan hasil produksi usaha tani yang dihasilkan kelompok tani.

f. Buku pembelian: diisi ketika ada pengeluaran uang yang digunakan untuk membeli barang berupa alat dan mesin pertanian serta bahan baku usaha tani berupa sarana produksi pertanian serta pupuk, pestisida.

Yang dapat diukur lewat:

- Baik (3) = buku ada, di isi lengkap dan benar.

- Kurang Baik (2) = buku ada tapi buku tidak diisi dengan lengkap.

- Tidak Baik (1) = buku tidak ada.

\section{Analisis Data}

\section{Administrasi Kegiatan}

Dari semua elemen yang ada disusun 11 pernyataan dengan total responden 3 kelompok tani. Setiap jawaban dihubungkan dengan bentuk pernyataan yang diungkapkan dengan kata-kata berikut:

Baik Skor : 3

Kurang Baik Skor : 2

Tidak Baik Skor : 1

Dengan cara perhitungan Range masingmasing pertanyaan:

Nilai Tertinggi : $3 \times 11=33$

Nilai Terendah : $1 \times 11=11$

Jumlah Kategori $=3$

$$
\begin{gathered}
\text { Range }=\frac{\text { Nilai } \text { Tertinggi-Nilai } \text { Terendah }}{\text { Jumlah } \text { Kategori }} \\
\text { Range }=\frac{33-11}{3}=7,33
\end{gathered}
$$

Jumlah skor ideal untuk setiap pernyataan (skor tertinggi) $=33$

Jumlah skor terendah $=11$

Range/Jangkauan $=7,33$

Dengan interpretasi nilai:

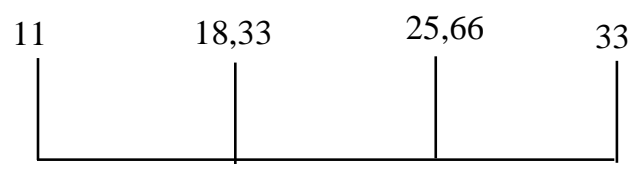

Tidak Baik Kurang Baik Baik

\begin{tabular}{cc}
\hline Interval & Kriteria \\
\hline $11-18,33$ & Tidak Baik \\
$18,34-25,66$ & Kurang Baik \\
$25,67-33$ & Baik \\
\hline
\end{tabular}

\section{Administrasi Keuangan}

Dari semua elemen yang ada disusun 6 pernyataan dengan total responden 3 kelompok tani. Setiap jawaban dihubungkan dengan bentuk pernyataan yang diungkapkan dengan kata-kata berikut:

$\begin{array}{ll}\text { Baik } & \text { Skor : } 3 \\ \text { Kurang Baik } & \text { Skor : } 2 \\ \text { Tidak Baik } & \text { Skor : } 1\end{array}$

Dengan cara perhitungan Range masingmasing pertanyaan:

Nilai Tertinggi : $3 \times 6=18$

Nilai Terendah : $1 \times 6=6$

Jumlah Kategori $=3$ 


$$
\begin{gathered}
\text { Range }=\frac{\text { Nilai Tertinggi-Nilai Terendah }}{\text { Jumlah Kategori }} \\
\text { Range }=\frac{18-6}{3}=4
\end{gathered}
$$

Jumlah skor ideal untuk setiap pernyataan (skor tertinggi) $=18$

Jumlah skor terendah $=6$

Range/Jangkauan $=4$

Dengan interpretasi nilai:

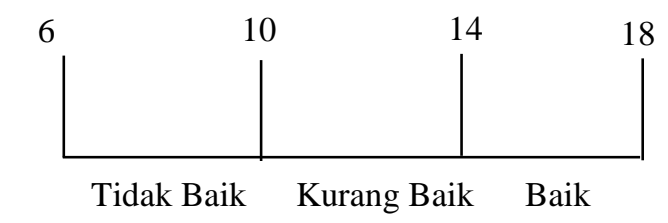

\begin{tabular}{cc}
\hline Interval & Kriteria \\
\hline $6-10$ & Tidak Baik \\
$10,05-14$ & Kurang Baik \\
$14,05-18$ & Baik
\end{tabular}

\section{HASIL DAN PEMBAHASAN}

\section{Geografis}

\section{Deskripsi Lokasi Penelitian}

Kecamatan Tomohon Utara merupakan bagian dari Kota Tomohon yang mempunyai batas-batas wilayah sebagai berikut:

a. Sebelah Utara dengan Kecamatan Peneleng, Kabupaten Minahasa.

b. Sebelah Timur dengan Gunung Mahawu.

c. Sebelah Selatan dengan Kelurahan Talete, Kecamatan Tomohon Tengah.

d. Sebelah Barat dengan Kelurahan Taratara, Kecamatan Tomohon Barat dan Gunung Lokon.

\section{Iklim}

Berdasarkan peta iklim Oldeman tipe iklim untuk lokasi Tomohon dan sekitarnya termasuk tipe iklim D1. Suhu udara rata-rata bulanan dari bulan ke bulan sepanjang tahun relatif kecil variasinya. Suhu rata-rata bulanan mencapai maksimum sekitar bulan Juli dan suhu rata-rata bulanan terendah sekitar bulan Januari. Suhu rata-rata hanya berfluktuasi antara $22.02^{\circ} \mathrm{C}$ pada bulan Januari sampai $22.8^{\circ} \mathrm{C}$.

\section{Karakteristik Kelompok Tani}

Kelompok tani pada dasarnya merupakan kelembagaan petani di pedesaan yang saling mengenal akrab dan saling percaya antara anggota kelompok tani, mempunyai pandangan dan kepentingan serta tujuan yang sama dalam berusaha tani. Kerja sama antara pengurus dengan anggota, anggota dengan penyuluh sangat berpengaruh bagi perkembangan usahatani dalam kelompok. Tabel 1 menunjukkan karakteristik kelompok tani.

\section{Karakteristik Responden}

\section{Umur Responden}

Tingkat umur mempengaruhi kemampuan seseorang dalam melakukan aktifitas maupun konsep berpikir khususnya tiap anggota kelompok tani. Anggota kelompok tani yang memiliki umur muda tentunya memiliki kondisi fisik yang lebih kuat, keinginan untuk mencoba hal baru, serta memiliki daya berpikir yang kreatif. Selain itu anggota kelompok tani yang berumur tua cenderung untuk lebih menjaga kesehatannya. Dari data primer yang di peroleh, usia responden kelompok tani antara 37-77 tahun. Komposisi umur responden dalam penelitian ini disajikan pada Tabel 2.

Tabel 2 menunjukkan bahwa jumlah responden dari 3 Kelompok Tani Rewoh Indah Kelurahan Kakaskasen Dua, Sinambey Mujair Kelurahan Kinilow dan Susuripen Kelurahan. Pada interval umur 41-50 tahun yaitu 4 orang yaitu Rewoh Indah dan Susuripen masing-masing 1 responden $(33,33 \%)$, sedangkan Sinambey Mujair 2 responden $(66,67 \%)$. Selanjutnya berada pada interval umur 51-60 tahun Sinambey Mujair dan Susuripen masing-masing 1 responden $(33,33 \%)$ dan yang berada pada interval 30-40 tahun, 61-70 tahun, $>70$ masing-masing $(33,33 \%)$ 1 responden.

\section{Jabatan Responden}

Jenis Jabatan sangat penting dalam mengelola atau menjalankan suatu organisasi, karena jabatan yang dimaksud disini adalah jabatan ketua, sekertaris dan bendahara dengan adanya ketua, sekertaris, bendahara organisasi akan berjalan dengan baik namun demikian jabatan ketua, sekertaris, bendahara harus tercipta kerjasama dengan anggota kelompok tani sehingga semua kegiatan dapat berjalan dengan baik. Tabel 3 menunjukkan jumlah responden menurut jenis jabatan.

Tabel 3 menunjukkan bahwa dalam penelitian ini terdapat 3 kategori jenis jabatan dari responden, yaitu ketua, sekertaris, bendahara, masing-masing sebanyak 3 responden $(33,33 \%)$. 


\section{Pendidikan Responden}

Tingkah laku individu atau seseorang sangat dipengaruhi oleh pendidikan yang telah dicapai. Begitu juga pada anggota kelompok tani, tingkat pendidikan dan pengalaman sangat mempengaruhi cara berpikir. Pada Tabel 4 menunjukkan tingkat pendidikan responden.

Pada Tabel 4 menunjukkan tingkat pendidikan pada kelompok tani Susuripen Kelurahan Wailan, dengan responden terbanyak yaitu SLTA sebanyak 3 responden (100\%), Begitu pula dengan kelompok tani Sinambey Mujair terdapat 2 responden yang mempunyai tingkat pendidikan SLTA $(66,67 \%)$ dan 1 responden yang mempunyai tingkat pendidikan S1 (33.33\%). Sedangkan Kelompok tani Rewoh Indah Kelurahan Kakaskasen Dua yang dekat dengan kantor BP3K, tingkat SMP sebanyak 1 responden $(33,33 \%)$, dan tingkat SLTA sebanyak 1 responden $(33,33 \%)$ juga tingkat S1 sebanyak 1 responden $(33,33 \%)$.

\section{Pengalaman Berusahatani}

Tingkah laku individu pada seseorang sangat dipengaruhi oleh lamanya berusahatani, karena mempengaruhi cara berpikir seseorang lebih lama kita bekerja lebih menambah wawasan seseorang anggota dalam setiap kegiatan dan lebih mengetahui apa yang belum diketahui oleh anggota yang baru. Tabel 5 menunjukkan jumlah responden menurut pengalaman bekerja.

Tabel 5 menunjukkan tingkat lamanya pengalaman berusaha tani setiap responden menjadi anggota kelompok tani terbanyak yaitu 12 tahun sebanyak 5 responden $(55,56 \%)$, sedangkan 9 tahun 3 responden $(33,33 \%)$, dan 5 tahun 1 responden $(11,11 \%)$.

Tabel 1. Karakteristik Kelompok Tani

\begin{tabular}{|c|c|c|c|c|c|}
\hline \multirow[t]{2}{*}{ No } & \multirow{2}{*}{$\begin{array}{c}\text { Karakteristik } \\
\text { Kelompok Tani }\end{array}$} & \multicolumn{3}{|c|}{ Kelompok Tani } & \multirow[b]{2}{*}{ Total } \\
\hline & & Rewoh Indah & Sinambey Mujair & Susuripen & \\
\hline 1 & Alamat & Kakaskasen 2 & Kinilow & Wailan & \\
\hline 2 & Tahun Terbentuk & 2004 & 2007 & 2004 & \\
\hline 3 & Jumlah Anggota & 6 & 10 & 20 & 36 \\
\hline
\end{tabular}

Sumber : Diolah dari data Primer 2016

Tabel 2. Jumlah Responden Menurut Tingkat Umur

\begin{tabular}{|c|c|c|c|c|c|c|c|}
\hline \multirow[t]{2}{*}{ No } & \multirow{2}{*}{$\begin{array}{l}\text { Umur } \\
\text { (Tahun) }\end{array}$} & \multicolumn{2}{|c|}{ Jumlah Responden } & \multicolumn{3}{|c|}{ Presentase (\%) } & \multirow[b]{2}{*}{ Susuripen } \\
\hline & & $\begin{array}{c}\text { Rewoh } \\
\text { Indah }\end{array}$ & $\begin{array}{c}\text { Sinambey } \\
\text { Mujair }\end{array}$ & Susuripen & $\begin{array}{c}\text { Rewoh } \\
\text { Indah }\end{array}$ & $\begin{array}{c}\text { Sinambey } \\
\text { Mujair }\end{array}$ & \\
\hline 1 & $30-40$ & 1 & - & - & 33,33 & & \\
\hline 2 & $41-50$ & 1 & 2 & 1 & 33,33 & 66,67 & 33,33 \\
\hline 3 & $51-60$ & - & 1 & 1 & & 33,33 & 33,33 \\
\hline 4 & $61-70$ & 1 & - & - & 33,33 & & \\
\hline \multirow[t]{2}{*}{5} & $>70$ & - & - & 1 & & & 33,33 \\
\hline & & 3 & 3 & 3 & 100 & 100 & 100 \\
\hline
\end{tabular}

Sumber : Diolah dari data Primer 2016

Tabel 3. Jumlah Responden Menurut Jenis Jabatan

\begin{tabular}{cccc}
\hline No & Jenis Jabatan & Jumlah Responden & Presentase (\%) \\
\hline 1 & Ketua & 3 & 33,33 \\
2 & Sekretaris & 3 & 33,33 \\
3 & Bendahara & 3 & 33,33 \\
\hline & Jumlah & 9 & 100 \\
\hline
\end{tabular}

Sumber : Diolah dari data Primer 2016 
Tabel 4. Jumlah Responden Menurut Tingkat Pendidikan

\begin{tabular}{lccccccc}
\hline No & $\begin{array}{c}\text { Tingkat } \\
\text { Pendidikan }\end{array}$ & \multicolumn{3}{c}{ Jumlah Responden } & \multicolumn{3}{c}{ Persentase (\%) } \\
\cline { 3 - 8 } & $\begin{array}{c}\text { Rewoh } \\
\text { Indah }\end{array}$ & $\begin{array}{c}\text { Sinambey } \\
\text { Mujair }\end{array}$ & Susuripen & $\begin{array}{c}\text { Rewoh } \\
\text { Indah }\end{array}$ & $\begin{array}{c}\text { Sinambey } \\
\text { Mujair }\end{array}$ & Susuripen \\
\hline 1 & SD & - & - & - & & & \\
2 & SMP & 1 & - & - & 33,33 & & \\
3 & SLTA & 1 & 2 & 3 & 33,33 & 66,67 & 100 \\
4 & S1 & 1 & 1 & - & 33,33 & 33,33 & \\
\hline & Jumlah & 3 & 3 & 3 & 100 & 100 & 100 \\
\hline
\end{tabular}

Sumber : Diolah dari data Primer 2016

Tabel 5. Jumlah Responden Menurut Pengalaman Berusahatani (Tahun)

\begin{tabular}{cccc}
\hline No & $\begin{array}{c}\text { Pengalaman Berusahatani } \\
\text { (Tahun) }\end{array}$ & Jumlah Responden & $\begin{array}{c}\text { Presentase } \\
(\boldsymbol{\%})\end{array}$ \\
\hline 1 & 5 & 1 & 11,11 \\
2 & 9 & 3 & 33,33 \\
3 & 12 & 5 & 55,56 \\
\hline & Jumlah & 9 & 100 \\
\hline
\end{tabular}

Sumber : Diolah dari data Primer 2016

\section{Administrasi Kegiatan dan Administrasi Keuangan Kelompok Tani Susuripen Kelurahan Wailan Kecamatan Tomohon Utara}

\section{Administrasi Kegiatan Kelompok Tani Susuripen Kelurahan Wailan Kecamatan Tomohon Utara}

Administrasi kegiatan merupakan penyusunan dan pencatatan data serta informasi, dengan tujuan untuk menyediakan keterangan. Kegiatan kerja sama yang dilakukan anggota kelompok tani berdasarkan pembagian kerja baik itu sebagai ketua, sekretaris dan bendahara. Administrasi kegiatan sangat penting bagi setiap organisasi kelompok tani yang menunjang kemajuan kelompok tani dimana semua kekurangan dan kelebihan dalam kelompok bisa kita ketahui melalui pembukuan administrasi kegiatan.

Kelompok Tani Susuripen kelurahan Wailan adalah suatu kelompok di wilayah kerja Balai Penyuluhan Pertanian Perikanan dan Kehutanan (BP3K) di Kecamatan Tomohon Utara, dan jarak tempuh dari BP3K menuju ke lokasi kelompok tani $\pm 2,4 \mathrm{~km}$. kelompok tani Susuripen adalah kelompok tani yang masih aktif dengan jumlah anggota 20 orang, berdiri mulai tahun 2004 sampai sekarang. Tanaman yang paling dominan di kelompok tani ini adalah padi, holtikultura dan jagung. Kelompok tani ini juga selalu mengadakan pertemuan setiap minggu. Peran aktif pemimpin kelompok sangat berpengaruh dalam kelangsungan kegiatan kelompok tani. Dengan mengikuti pelatihan di Bogor pada tahun 2015, ketua kelompok tani Susuripen dapat menerapkan apa yang dipelajari di sana kepada kelompok yang dipimpinnya. Administrasi kegiatan kelompok tani Susuripen di kelurahan Wailan dapat dilihat pada Tabel 6.

Dari hasil penelitian pada kelompok tani Rewoh Indah, kerja sama dari pengurus dan anggota sangat penting dalam kelangsungan kegiatan organisasi, pada kelompok tani Susuripen, pengurus menjalankan tugas sebagaimana mestinya, sehingga administrasi kelompok tani berjalan dengan baik, selain itu pengaruh PPL yang merupakan penyuluh terbaik di Kota Tomohon juga membuat peningkatan terhadap kelengkapan administrasi kelompok tani. Ada beberapa buku administrasi kegiatan kelompok yang kriteria dikatakan baik (3) dan kriteria kurang baik (1) dengan jumlah skor (30). Masing-masing sebagai berikut:

1). Buku Induk anggota, buku induk anggota adalah kegiatan yang dilakukan dalam suatu organisasi untuk mencatat semua nama-nama anggota yang ada dalam kelompok tani. Hasil penelitian ini menunjukan bahwa buku induk anggota dengan kriteria baik (3). Buku ada dan diisi dengan lengkap oleh pengurus kelompok, dan juga tidak ada kendala dalam pembuatan buku induk anggota kelompok.

2). Buku Tamu, buku tamu juga menunjang kemajuan kelompok tani Susuripen, buku tamu memungkinkan kelompok tani untuk 
mengetahui lebih lanjud pengunjung yang datang. Data yang diperoleh dari kelompok tani Susuripen baik (3) karena buku sudah disiapkan dan setiap tamu yang berkunjung siap untuk mengisi data kunjungan.

3). Buku Notulen Rapat, buku notulen sangat berpengaruh bagi suatu organisasi kelompok, buku notulen catat mencatat ketika menggikuti pertemuan memungkinkan kelompok mengetahui hal-hal yang penting untuk mengembangkan kelompok tani. Buku notulen rapat pada kelompok tani susuripen kelurahan Wailan dikatakan baik dan masuk pada kriteria (3) karena buku ada dan diisi lengkap oleh sekertaris.

4). Buku Kegiatan kelompok, buku kegiatan kelompok yaitu semua kegiatan yang dilakukan oleh kelompok tani baik didalam ruangan maupun diluar ruangan dan dicatat dalam pembukuan. Hasil dari penelitian ini menunjukan bahwa setiap kegiatan kelompok tani Susuripen baik penanaman, rapat dan lain-lain yang berhubungan dengan kelompok tani selalu dicatat oleh sekertaris sehingga kriteria baik (3) buku ada dan diisi lengkap.

5). Buku produktifitas dan hasil produksi, sangat dibutuhkan dalam kegiatan kelompok, yang didalamnya berisi catatan tentang hasil panen yang diterima. Dengan adanya kerjasama dari penyuluh, dan pengurus kelompok sehingga buku produktifitas dan hasil produksi berjalan dengan baik (3), buku ada dan diisi lengkap oleh sekertaris kelompok.

6). Buku agenda surat masuk dan surat keluar untuk mencatat surat yang diterima oleh kelompok, juga mencatat surat yang dikirim untuk siapa beserta nomor surat. Dan pengurus kelompok tani Susuripen selalu memperhatikan surat-surat yang masuk dan yang keluar dan dicatat dalam buku sehingga mendapat kriteria baik (3) karena buku ada dan diisi lengkap.

7). Buku ekspedisi merupakan buku pengantar surat untuk mencatat pengiriman surat kepada pihak lain. Kriteria buku ekspedidi dikatakan kurang baik (2) karena buku ada tapi tidak diisi dengan lengkap dan benar.

8). Buku kepemilikan sarana/prasarana anggota yaitu dokumen tertulis yang berisi tentang jenis-jenis sarana dan prasarana pertanian seperti alat-alat dan mesin pertanian yang dimiliki anggota kelompok. Dari hasil penelitian ini dikatakan kurang baik (2) karena buku ada tapi tidak diisi dengan lengkap dan benar.

9). Buku luas Lahan Garapan dan usaha tani anggota, dokumen tertulis yang berisi tentang luas areal lahan garapan anggota kelompok berupa lahan sawah, pekarangan, tegalan, kebun serta jenis-jenis usahatani yang dijalankan para anggota. Hasil penelitian yang didapat yaitu kurang baik (2) karena buku ada tapi tidak diisi dengan lengkap dan benar.

10). Buku Pengurus adalah buku yang berisi tentang biodata setiap petani yang menjadi pengurus kelompok. Buku ini bermanfaat untuk mengetahui nama - nama pengurus di setiap periode kepengurusan yang disepakati. Dan dalam penelitian ini didapatkan hasil yang baik (3) karena buku ada, diisi dengan lengkap dan benar.

11). Buku daftar hadir yaitu dokumen yang berisi kehadiran petani yang menjadi anggota kelompok dam setiap kali kelompok mengadakan kegiatan. Dan di kelompok tani Susuripen sendiri mempunyai buku dan diisi dengan lengkap sehingga mendapatkan kriteria yang baik (3).

Untuk mengetahui kelengkapan administrasi kegiatan pada kelompok tani Susuripen, maka perlu dihitung jumlah keseluruhan skor pada setiap kriterium. Pada penelitian ini jumlah skor ideal (tertinggi), yaitu 33, dan jumlah skor terendah, yaitu 11. Berdasarkan data yang dihimpun dari 11 indikator pernyataan yang diajukan kepada 3 responden, maka diperoleh total skor 30 dengan kriteria baik. Letak skor ditentukan dalam jangkauan sebagai berikut berikut:

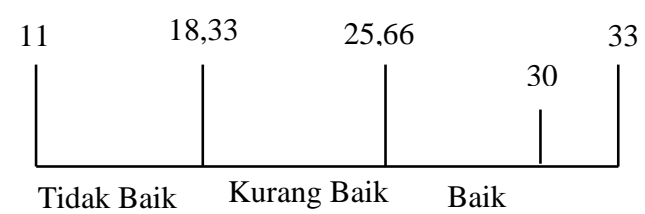

\section{Administrasi Keuangan Kelompok Tani Susuripen Kelurahan Wailan Kecamatan Tomohon Utara}

Tabel 7 menunjukan administrasi keuangan kelompok tani Susuripen Kelurahan Wailan Kecamatan Tomohon Utara Kota Tomohon.

Administrasi keuangan kelompok tani Susuripen kelurahan Wailan dikatakan kurang baik dalam pembuatan buku kelengkapan administrasi keuangan kelompok. Hal tersebut 
dikarenakan buku keuangan tidak dipegang langsung oleh bendahara kelompok sehingga kelengkapan administrasi keuangan mempunyai 2 buku yang mendapat skor (1), 3 buku yang mempunyai skor (2), dan hanya ada 1 buku yang mempunyai kriteria baik dengan skor (3), dengan jumlah skor seluruhnya yaitu (11).

1) Buku kas adalah buku yang mencatat tentang segala kegiatan yang dilaksanakan oleh kelompok yang menyangkut pengeluaran dan pemasukan keuangan kelompok. Dari hasil data yang didapatkan bahwa buku kas mendapat kriteria kurang baik dengan bobot (2) buku ada tapi tidak diisi dengan lengkap dan benar.

2) Buku iuran anggota yaitu buku yang mencatat tentang masuknya iuran dalam bentuk uang tunai maupun natura ke dalam kas kelompok. Hasil penelitian buku iuran anggota dikatakan tidak baik dengan bobot (1) karena buku tidak ada.

3) Buku tabungan anggota adalah buku yang mencatat tentang masuknya tabungan dalam bentuk uang tunai maupun natura ke dalam kas kelompok. Dari hasil penelitian buku tabungan anggota tidak baik karena tidak ada buku tabuangan sehingga mendapat bobot (1)

4) Buku Inventaris, dokumen tertulis yang berisi tentang jenis barang, sarana dan prasarana pertanian seperti alat-alat dan mesin pertanian yang dimiliki kelompok baik yang berasal dari pembelian yang dilakukan kelompok tani maupun dari bantuan pemerintah. Buku inventaris dikatakan baik (3) karena buku ada dan diisi dengan lengkap dan benar oleh pengurus.
5) Buku penjualan adalah buku yang mencatat tentang segala kegiatan penjualan hasil produksi usahatani yang dihasilkan kelompok tani yang dilaksanakan oleh anggota kelompok. Dari hasil penelitian ini dikatakan kurang baik (2) karena buku ada tapi tidak diisi dengan lengkap dan benar.

6) Buku pembelian yaitu buku yang mencatat tentang segala kegiatan pengeluaran uang yang dipergunakan untuk membeli barang berupa alat dan mesin pertanian serta bahan baku usahatani berupa sarana produksi pertanian seperti pupuk, pestisida. Hasil penelitian menunjukan bahwa buku pembelian kelompok tani susuripen ada tapi tidak diisi dengan lengkap dan benar maka dikatakan kurang baik dengan skor (2).

Untuk mengetahui kelengkapan administrasi keuangan pada kelompok tani Susuripen, maka perlu dihitung jumlah keseluruhan skor pada setiap kriterium. Pada penelitian ini jumlah skor ideal (tertinggi), yaitu 18, dan jumlah skor terendah, yaitu 6. Berdasarkan data yang dihimpun dari sebanyak 6 indikator pernyataan yang diajukan kepada 3 responden, maka diperoleh total skor 11 dengan kriteria kurang baik. Letak skor ditentukan dalam jangkauan sebagai berikut berikut:

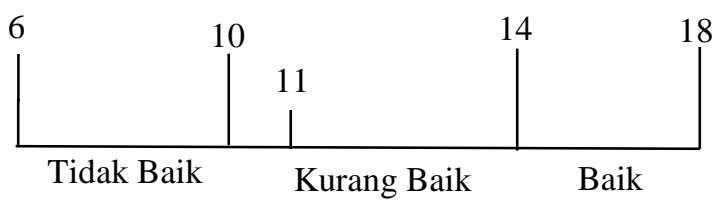

Tabel 6. Administrasi Kegiatan Kelompok Tani Susuripen kelurahan Wailan

\begin{tabular}{clcc}
\hline No & Administrasi Kegiatan & Alternative Skor & Alternative Jawaban \\
\hline 1 & Buku Induk Anggota & 3 & Baik \\
2 & Buku Tamu & 3 & Baik \\
3 & Buku Notulen Rapat & 3 & Baik \\
4 & Buku Kegiatan Kelompok & 3 & Baik \\
5 & Buku Produktifitas dan Hasil Produksi & 3 & Baik \\
6 & Buku Agenda Surat Masuk dan Surat Keluar & 3 & Baik \\
7 & Buku Ekspedisi & 2 & Kurang Baik \\
8 & Buku Kepemilikan Sarana/ Prasarana Anggota & 2 & Kurang Baik \\
9 & Buku Luas Lahan Garapan & 2 & Kurang Baik \\
10 & Buku Pengurus & 3 & Baik \\
11 & Buku Daftar Hadir & 3 & Baik \\
\hline & Jumlah & 30 & \\
\hline
\end{tabular}

Sumber: Diolah dari data primer 2016 
Tabel 7. Administrasi Keuangan Kelompok Tani Susuripen di Kelurahan Wailan

\begin{tabular}{clcc}
\hline No & Administrasi Keuangan & Alternative Skor & Alternative Jawaban \\
\hline 1 & Buku Kas & 2 & Kurang Baik \\
2 & Buku Iuran Anggota & 1 & Tidak Baik \\
3 & Buku Tabungan Anggota & 1 & Tidak Baik \\
4 & Buku Inventaris & 3 & Baik \\
5 & Buku Penjualan & 2 & Kurang Baik \\
6 & Buku Pembelian & 2 & Kurang Baik \\
\hline & Jumlah & 11 & \\
\hline
\end{tabular}

Sumber: Diolah dari data primer 2016

\section{Administrasi Kegiatan dan Administrasi Keuangan Kelompok Tani Rewoh Indah Kelurahan Kakaskasen Dua Kecamatan Tomohon Utara Kota Tomohon}

\section{Administrasi Kegiatan Kelompok Tani Rewoh Indah Kelurahan Kakskasen Dua Kecamatan Tomohon Utara}

Kelompok tani Rewoh Indah Kelurahan

Kakaskasen Dua merupakan kelompok tani yang berada sangat dekat dengan Balai Penyuluhan Pertanian Perikanan dan Kehutanan (BP3K) di Kecamatan Tomohon Utara, kelompok tani Rewoh Indah adalah kelompok tani yang masih aktif yang berdiri pada tahun 2004, dengan jumlah anggota 6 orang. Tanaman yang paling dominan di kelompok tani ini adalah Bunga Krisan. Tabel 8 menunjukan kelengkapan administrasi kegiatan kelompok tani Rewoh Indah Kelurahan Kakaskasen Dua Kecamatan Tomohon Utara.

Dari hasil penelitian ini didapatkan bahwa kelengkapan administrasi kegiatan kelompok tani tidak berjalan dengan baik karena tidak adanya kerja sama yang baik antara penyuluh dengan pengurus dan pengurus dengan anggota. Tidak terjalinnya kebersamaan dalam kelompok tani karena pengurus yang lain sudah dengan kesibukan masing-masing, menurut sekertaris sudah kurang lebih 5 tahun kelompok tani Rewoh Indah tidak memiliki kelengkapan administrasi dikarenakan kurangnya sosialisasi kepada anggota dari penyuluh sehingga menyebabkan administrasi kelompok tidak berjalan dengan baik. Semua administrasi kegiatan mempunyai kriteria tidak baik (1) karena buku tidak ada, jadi jumlah skor adalah (11). Hasil penelitian yang diperoleh yaitu :

1). Dari hasil penelitian ini menunjukan bahwa buku induk anggota dinilai tidak baik dengan bobot (1) karena buku tidak ada.
2). Buku Tamu, buku tamu juga dinilai tdak baik dengan bobot (1) karena buku tidak ada.

3). Dari hasil penelitian ini menunjukan bahwa buku notulen rapat dinilai tidak baik dengan bobot (1) karena buku tidak ada

4). Dari hasil penelitian ini menunjukan bahwa buku kegiatan kelompok dinilai tidak baik dengan bobot (1) karena buku tidak ada.

5). Buku produktifitas dan hasil produksi, dari hasil penelitian ini menunjukan bahwa buku produktifitas dan hasil produksi dinilai tidak baik dengan bobot (1) karena buku tidak ada.

6). Buku agenda surat masuk dan surat keluar, dari hasil penelitian ini menunjukan bahwa buku agenda surat masuk dan surat keluar dinilai tidak baik dengan bobot (1) karena buku tidak ada.

7). Buku ekspedisi merupakan buku pengantar surat untuk mencatat pengiriman surat kepada pihak lain. Kriteria buku ekspedidi dikatakan tidak baik (1) karena buku tidak ada.

8). Buku kepemilikan sarana/prasarana anggota yaitu dokumen tertulis yang berisi tentang jenis -jenis sarana dan prasarana pertanian seperti alat-alat dan mesin pertanian yang dimiliki anggota kelompok. Dari hasil penelitian ini dikatakan tidak baik (1) karena buku tidak ada.

9). Buku luas Lahan Garapan dan usaha tani anggota, dokumen tertulis yang berisi tentang luas areal lahan garapan anggota kelompok berupa lahan sawah,pekarangan, tegalan, kebun serta jenis-jenis usahatani yang dijalankan para anggota. Hasil penelitian yang didapat yaitu tidak baik (1) karena buku tidak ada.

10). Buku Pengurus adalah buku yang berisi tentang biodata setiap petani yang menjadi pengurus kelompok. Buku ini bermanfaat untuk mengetahui nama - nama pengurus di setiap periode kepengurusan yang disepakati. 
Dan dalam penelitian ini didapatkan hasil yang tidak baik (1) karena buku tidak ada.

11). Buku daftar hadir yaitu dokumen yang berisi kehadiran petani yang menjadi anggota kelompok dam setiap kali kelompok mengadakan kegiatan. Dari hasil penelitian ini menunjukan bahwa buku daftar hadir dinilai tidak baik dengan bobot (1) karena buku tidak ada.

Untuk mengetahui kelengkapan administrasi kegiatan pada kelompok tani Rewoh Indah, maka perlu dihitung jumlah keseluruhan skor pada setiap kriterium. Pada penelitian ini jumlah skor ideal (tertinggi), yaitu 33, dan jumlah skor terendah, yaitu 11. Berdasarkan data yang dihimpun dari sebanyak 11 indikator pernyataan yang diajukan kepada 3 responden, maka diperoleh total skor 11 dengan kriteria tidak baik. Letak skor ditentukan dalam jangkauan sebagai berikut berikut:

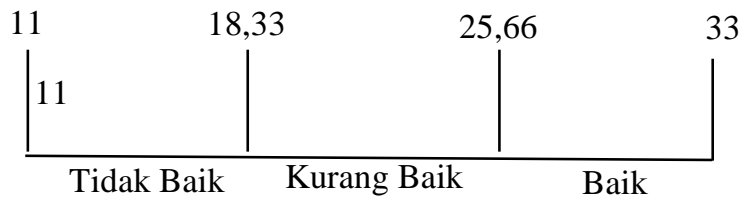

\section{Administrasi Keuangan Kelompok Tani Rewoh Indah Kelurahan Kakaskasen Dua Kecamatan Tomohon Utara}

Berikut ini dapat dilihat kelengkapan administrasi keuangan kelompok. Tabel 9 menumjukan administrasi keuangan kelompok tani Rewoh Indah Kelurahan Kakaskasen Dua Kecamatan Tomohon Utara Kota Tomohon.

Dari hasil penelitian menunjukan bahwa administrasi keuangan pada kelompok tani Rewoh Indah tidak berjalan dengan baik. Hal itu disebabkan karena bendahara kelompok sudah tidak terlalu aktif karena mempunyai pekerjaan lain sehingga administrasi keuangan kelompok tani tidak berjalan baik dengan skor

(1) dan jumlah skor yaitu (6).

1) Buku kas adalah buku yang mencatat tentang segala kegiatan yang dilaksanakan oleh kelompok yang menyangkut pengeluaran dan pemasukan keuangan kelompok. Dari hasil data yang didapatkan bahwa buku kas mendapat kriteria tidak baik (2) karena buku tidak ada.

2) Buku iuran anggota yaitu buku yang mencatat tentang masuknya iuran dalam bentuk uang tunai maupun natura ke dalam kas kelompok.
Hasil penelitian buku iuran anggota dikatakan tidak baik dengan bobot (1) karena buku tidak ada.

3) Buku tabungan anggota adalah buku yang mencatat tentang masuknya tabungan dalam bentuk uang tunai maupun natura ke dalam kas kelompok. Dari hasil penelitian buku tabungan anggota tidak baik karena tidak ada buku tabuangan sehingga mendapat bobot (1)

4) Buku Inventaris, dokumen tertulis yang berisi tentang jenis barang, sarana dan prasarana pertanian seperti alat-alat dan mesin pertanian yang dimiliki kelompok baik yang berasal dari pembelian yang dilakukan kelompok tani maupun dari bantuan pemerintah. Buku inventaris dikatakan tidak baik (1) karena buku tidak ada..

5) Buku penjualan adalah buku yang mencatat tentang segala kegiatan penjualan hasil produksi usahatani yang dihasilkan kelompok tani yang dilaksanakan oleh anggota kelompok. Dari hasil penelitian ini dikatakan tidak baik (1) karena buku tidak ada.

6) Buku pembelian yaitu buku yang mencatat tentang segala kegiatan pengeluaran uang yang dipergunakan untuk membeli barang berupa alat dan mesin pertanian serta bahan baku usahatani berupa sarana produksi pertanian seperti pupuk, pestisida. Hasil penelitian menunjukan bahwa buku pembelian kelompok tani susuripen tidak ada maka dikatakan tidak baik dengan bobot (1).

Untuk mengetahui kelengkapan administrasi keuangan pada kelompok tani Rewoh Indah, maka perlu dihitung jumlah keseluruhan skor pada setiap kriterium. Pada penelitian ini jumlah skor ideal (tertinggi), yaitu 18, dan jumlah skor terendah, yaitu 6 . Berdasarkan data yang dihimpun dari sebanyak 6 indikator pernyataan yang diajukan kepada 3 responden, maka diperoleh total skor 6 dengan kriteria tidak baik. Letak skor ditentukan dalam jangkauan sebagai berikut berikut:

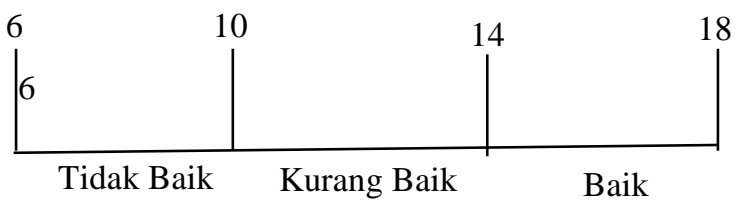


Tabel 8. Administrasi Kegiatan Kelompok Tani Rewoh Indah kelurahan Kakaskasen Dua

\begin{tabular}{clcc} 
No & Administrasi Kegiatan & Alternative Skor & Alternative Jawaban \\
\hline 1 & Buku Induk Anggota & 1 & Tidak Baik \\
2 & Buku Tamu & 1 & Tidak Baik \\
3 & Buku Notulen Rapat & 1 & Tidak Baik \\
4 & Buku Kegiatan Kelompok & 1 & Tidak Baik \\
5 & Buku Produktifitas dan Hasil Produksi & 1 & Tidak Baik \\
6 & Buku Agenda Surat Masuk dan Surat Keluar & 1 & Tidak Baik \\
7 & Buku Ekspedisi & 1 & Tidak Baik \\
8 & Buku Kepemilikan Sarana/ Prasarana Anggota & 1 & Tidak Baik \\
9 & Buku Luas Lahan Garapan & 1 & Tidak Baik \\
10 & Buku Pengurus & 1 & Tidak Baik \\
11 & Buku Daftar Hadir & 1 & Tidak Baik \\
\hline
\end{tabular}

Sumber: Diolah dari data primer 2016

Tabel 9. Administrasi Keuangan Kelompok Tani Rewoh Indah kelurahan Kakaskasen Dua

\begin{tabular}{clcc} 
No & Administrasi Keuangan & Alternative Skor & Alternative Jawaban \\
\hline 1 & Buku Kas & 1 & Tidak Baik \\
2 & Buku Iuran Anggota & 1 & Tidak Baik \\
3 & Buku Tabungan Anggota & 1 & Tidak Baik \\
4 & Buku Inventaris & 1 & Tidak Baik \\
5 & Buku Penjualan & 1 & Tidak Baik \\
6 & Buku Pembelian & 1 & Tidak Baik \\
\hline & Jumlah & 6 & \\
\hline
\end{tabular}

Sumber: Diolah dari data primer 2016

\section{Administrasi Kegiatan dan Administrasi Keuangan Kelompok Tani Sinambey Mujair Kelurahan Kinilow Kecamatan Tomohon Utara Kota Tomohon}

\section{Administrasi Kegiatan Kelompok Sinambey Mujair Kelurahan Kinilow Kecamatan Tomohon Utara \\ Kelompok tani Sinambey Mujair} kelurahan Kinilow merupakan kelompok tani yang berada paling jauh dengan Balai Penyuluhan Pertanian Perikanan dan Kehutanan (BP3K) di Kecamatan Tomohon Utara, kelompok tani Sinambey Mujair adalah kelompok tani yang masih aktif dengan jumlah anggota 10 orang, berdiri mulai tahun 2007 sampai sekarang. Kelompok ini bergerak di bidang pemijahan ikan, diantaranya ikan Mas, Nila dan Koi. Ketua kelompok beberapa kali mendapatkan penghargaan sekaligus bantuan dari Gerakan Pakan Mandiri, dan menjadi kelompok terbaik se Kota Tomohon, juga pernah mendapat peringkat ke-2 se Provinsi Sulawesi Utara. Pertemuan diadakan 2 minggu sekali setiap tanggal 15 dan tanggal 30. Tabel 10 menunjukan kelengkapan administrasi kegiatan kelompok tani Sinambey Mujair Kelurahan Kinilow Kecamatan Tomohon Utara.

Dari hasil penelitian, ada 8 buku yang mempunyai skor (3) yaitu buku ada dan diisi dengan lengkap dan benar, 3 buku yang mempunyai skor (2) yaitu buku ada tapi tidak diisi dengan lengkap dan benar, dengan jumlah skor (30). Hal itu disebabkan karena keaktifan pengurus dan anggota dalam kegiatan kelompok tani, serta manajemen yang baik, juga kerja sama yang baik antara pengurus dan anggota, penyuluh dan semua anggota kelompok tani. Dan adanya pengetahuan kelompok tani tentang kelengkapan administrasi kegiatan walaupun masih ada beberapa buku yang belum dilengkapi.

1) Buku Induk anggota, buku induk anggota adalah kegiatan yang dilakukan dalam suatu organisasi untuk mencatat semua nama-nama anggota yang ada dalam kelompok tani. Hasil penelitian ini menunjukan bahwa buku induk 
anggota dengan kriteria baik (3). Buku ada dan diisi dengan lengkap oleh pengurus kelompok, dan juga tidak ada kendala dalam pembuatan buku induk anggota kelompok.

2) Buku Tamu, buku tamu juga menunjang kemajuan kelompok tani, buku tamu memungkinkan kelompok tani untuk mengetahui lebih lanjud pengunjung yang dating. Data yang diperoleh dari kelompok tani Sinambey Mujair baik (3) karena buku sudah disiapkan dan setiap tamu yang berkunjung siap untuk mengisi data kunjungan.

3) Buku Notulen Rapat, buku notulen sangat berpengaruh bagi suatu organisasi kelompok, buku notulen catat mencatat ketika menggikuti pertemuan memungkinkan kelompok mengetahui hal-hal yang penting untuk mengembangkan kelompok tani. Buku notulen rapat pada kelompok tani Sinambey Mujair dikatakan baik dengan skor (3) karena buku ada dan diisi lengkap oleh sekretaris.

4) Buku Kegiatan kelompok, buku kegiatan kelompok yaitu semua kegiatan yang dilakukan oleh kelompok tani baik didalam ruangan maupun diluar ruangan dan dicatat dalam pembukuan. Hasil dari penelitian ini menunjukan bahwa setiap kegiatan kelompok tani baik penanaman, rapat dan lain-lain yang berhubungan dengan kelompok tani selalu dicatat oleh sekertaris sehingga kriteria baik (3) buku ada dan diisi lengkap. Dan buku di tulis dengan nama (buku rencana kerja) dan (buku hasil rencana kerja).

5) Buku produktifitas dan hasil produksi, sangat dibutuhkan dalam kegiatan kelompok, yang didalamnya berisi catatan tentang hasil panen yang diterima. Dengan adanya kerjasama dari penyuluh, dan pengurus kelompok sehingga buku produktifitas dan hasil produksi berjalan dengan baik (3), buku ada dan diisi lengkap oleh sekertaris kelompok. Nama buku diganti dengan Buku Penebaran dan Produksi.

6) Buku agenda surat masuk dan surat keluar untuk mencatat surat yang diterima oleh kelompok dan mencatat surat yang dikirim untuk siapa beserta nomor surat. Dan pengurus kelompok tani Sinambey Mujair selalu memperhatikan surat-surat yang masuk dan yang keluar dan dicatat dalam buku sehingga mendapat kriteria baik (3) karena buku ada dan diisi lengkap.
7) Buku ekspedisi merupakan buku pengantar surat untuk mencatat pengiriman surat kepada pihak lain. Kriteria buku ekspedidi dikatakan kurang baik (2) karena buku ada tapi tidak diisi dengan lengkap dan benar.

8) Buku kepemilikan sarana/prasarana anggota yaitu dokumen tertulis yang berisi tentang jenis-jenis sarana dan prasarana pertanian seperti alat-alat dan mesin pertanian yang dimiliki anggota kelompok. Dari hasil penelitian ini dikatakan kurang baik dengan bobot (2) karena buku ada tapi tidak diisi dengan lengkap dan benar.

9) Buku luas Lahan Garapan dan usaha tani anggota, dokumen tertulis yang berisi tentang luas areal lahan garapan anggota kelompok berupa lahan sawah,pekarangan, tegalan, kebun serta jenis-jenis usahatani yang dijalankan para anggota. Hasil penelitian yang didapat yaitu baik (2) karena buku ada tapi tidak diisi dengan lengkap dan benar.

10) Buku Pengurus adalah buku yang berisi tentang biodata setiap petani yang menjadi pengurus kelompok. Buku ini bermanfaat untuk mengetahui nama - nama pengurus di setiap periode kepengurusan yang disepakati. Dan dalam penelitian ini didapatkan hasil yang baik (3) karena buku ada dan diisi dengan lengkap dan benar.

11) Buku daftar hadir yaitu dokumen yang berisi kehadiran petani yang menjadi anggota kelompok dam setiap kali kelompok mengadakan kegiatan. Dan di kelompok tani Sinambey Mujair sendiri mempunyai buku dan diisi dengan lengkap dan benar sehingga mendapatkan kriteria yang baik (3).

Untuk mengetahui kelengkapan administrasi kegiatan pada kelompok tani Sinambey Mujair, maka perlu dihitung jumlah keseluruhan skor pada setiap kriterium. Pada penelitian ini jumlah skor ideal (tertinggi), yaitu 33, dan jumlah skor terendah, yaitu 11. Berdasarkan data yang dihimpun dari sebanyak 11 indikator pernyataan yang diajukan kepada 3 responden, maka diperoleh total skor 30 dan masuk pada kriteria baik, dengan letak skor ditentukan dalam jangkauan sebagai berikut berikut:

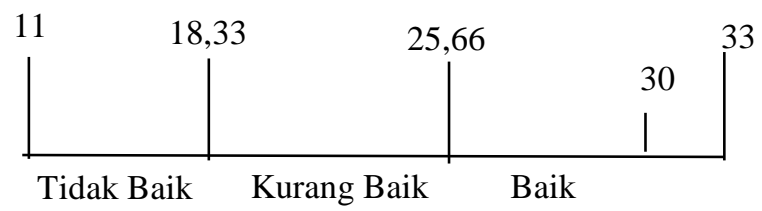




\section{Administrasi Keuangan Kelompok Tani Sinambey Mujair Kelurahan Kinilow Kecamatan Tomohon Utara}

Berikut ini adalah hasil penelitian tentang administrasi Keuangan Kelompok Tani Sinambey Mujair. Tabel 11 menunjukan administrasi keuangan kelompok tani Sinambey Mujair Kelurahan Kinilow Kecamatan Tomohon Utara Kota Tomohon.

Administrasi keuangan kelompok Sinambey Mujair kelurahan Kinilow dikatakan baik (3) dengan jumlah skor (18). Hal tersebut dikarenakan adanya kerja sama yang baik dari pengurus kelompok tani Sinambey Mujair.

1) Buku kas adalah buku yang mencatat tentang segala kegiatan yang dilaksanakan oleh kelompok yang menyangkut pengeluaran dan pemasukan keuangan kelompok. Dari hasil data yang didapatkan bahwa buku kas mendapat kriteria baik (3) karena buku ada dan diisi lengkap dan benar.

2) Buku iuran anggota yaitu buku yang mencatat tentang masuknya iuran dalam bentuk uang tunai maupun natura ke dalam kas kelompok. Hasil penelitian buku iuran anggota dikatakan baik karena setiap kali pertemuan seluruh anggota mengumpulkan iuran sebesar Rp.5000 sehingga memiliki bobot (3) karena buku dan diisi lengkap dan benar.

3) Buku tabungan anggota adalah buku yang mencatat tentang masuknya tabungan dalam bentuk uang tunai maupun natura ke dalam kas kelompok. Dari hasil penelitian buku tabungan anggota baik karena setiap kali pertemuan kelompok anggota melakukan arisan sehingga mendapat bobot (3) buku ada, diisi dengan lengkap dan benar.

4) Buku Inventaris, dokumen tertulis yang berisi tentang jenis barang, sarana dan prasarana pertanian seperti alat-alat dan mesin pertanian yang dimiliki kelompok baik yang berasal dari pembelian yang dilakukan kelompok tani maupun dari bantuan pemerintah. Buku inventaris dikatakan baik (3) karena buku ada dan diisi dengan lengkap dan benar oleh pengurus.

5) Buku penjualan adalah buku yang mencatat tentang segala kegiatan penjualan hasil produksi usahatani yang dihasilkan kelompok tani yang dilaksanakan oleh anggota kelompok. Dari hasil penelitian ini dikatakan tidak baik (3) karena buku ada, diisi lengkap tapi dengan nama yang berbeda yaitu buku pemasaran.

6) Buku pembelian yaitu buku yang mencatat tentang segala kegiatan pengeluaran uang yang dipergunakan untuk membeli barang berupa alat dan mesin pertanian serta bahan baku usahatani berupa sarana produksi pertanian seperti pupuk, pestisida. Hasil penelitian menunjukan bahwa buku pembelian kelompok tani Sinambey Mujair ada dan diisi dengan lengkap dan benar maka dikatakan baik dengan bobot (3).

Untuk mengetahui kelengkapan administrasi keuangan pada kelompok tani Sinambey Mujair, maka perlu dihitung jumlah keseluruhan skor pada setiap kriterium. Pada penelitian ini jumlah skor ideal (tertinggi), yaitu 18, dan jumlah skor terendah, yaitu 6 . Berdasarkan data yang dihimpun dari sebanyak 6 indikator pernyataan yang diajukan kepada 3 responden, maka diperoleh total skor 18 dengan kriteria baik. Letak skor ditentukan dalam jangkauan sebagai berikut berikut:

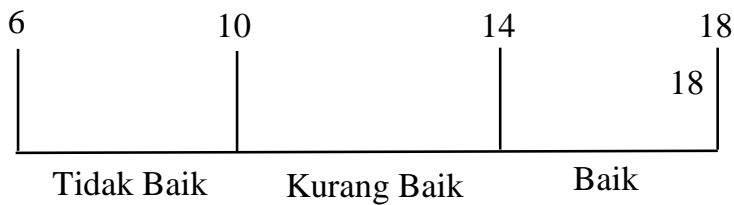

Tabel 10. Administrasi Kegiatan Kelompok Tani Sinambey Mujair kelurahan Kinilow

\begin{tabular}{clcc}
\hline No & Administrasi Kegiatan & Alternative Skor & Alternative Jawaban \\
\hline 1 & Buku Induk Anggota & 3 & Baik \\
2 & Buku Tamu & 3 & Baik \\
3 & Buku Notulen Rapat & 3 & Baik \\
4 & Buku Kegiatan Kelompok & 3 & Baik \\
5 & Buku Produktifitas dan Hasil Produksi & 3 & Baik \\
6 & Buku Agenda Surat Masuk dan Surat Keluar & 3 & Baik \\
7 & Buku Ekspedisi & 2 & Kurang Baik \\
8 & Buku Kepemilikan Sarana/ Prasarana Anggota & 2 & Kurang Baik \\
9 & Buku Luas Lahan Garapan & 2 & Kurang Baik \\
10 & Buku Pengurus & 3 & Baik \\
11 & Buku Daftar Hadir & 3 & Baik \\
\hline
\end{tabular}

Sumber: Diolah dari data primer 2016 
Tabel 11. Administrasi Keuangan Kelompok Tani Sinambey Mujair kelurahan Kinilow

\begin{tabular}{|c|c|c|c|}
\hline No & Administrasi Keuangan & Alternative Skor & Alternative Jawaban \\
\hline 1 & Buku Kas & 3 & Baik \\
\hline 2 & Buku Iuran Anggota & 3 & Baik \\
\hline 3 & Buku Tabungan Anggota & 3 & Baik \\
\hline 4 & Buku Inventaris & 3 & Baik \\
\hline 5 & Buku Penjualan & 3 & Baik \\
\hline \multirow[t]{2}{*}{6} & Buku Pembelian & 3 & Baik \\
\hline & Jumlah & 18 & \\
\hline
\end{tabular}

Sumber: Diolah dari data primer 2016

Tabel 12. Perbandingan Tiga Kelompok Tani

\begin{tabular}{|c|c|c|c|c|c|}
\hline \multirow[t]{2}{*}{ No } & \multirow[t]{2}{*}{ Informasi } & \multicolumn{3}{|c|}{ Kelompok Tani } & \multirow[b]{2}{*}{ Ket } \\
\hline & & Susuripen & Rewoh Indah & $\begin{array}{l}\text { Sinambey } \\
\text { Mujair }\end{array}$ & \\
\hline 1 & Tahun Berdiri & 2004 & 2004 & 2007 & \\
\hline 2 & Jarak BP3K & $2,4 \mathrm{~km}$ & $300 \mathrm{~m}$ & $9,9 \mathrm{~km}$ & \\
\hline 3 & Jumlah Anggota & 20 & 6 & 10 & \\
\hline 4 & Jenis Kelamin: & & & & \\
\hline & Laki-laki & 14 & 5 & 10 & \\
\hline & Perempuan & 6 & 1 & & \\
\hline 5 & Umur: & & & & \\
\hline & Ketua & 50 & 61 & 57 & \\
\hline & Sekretaris & 77 & 37 & 42 & \\
\hline & Bendahara & 54 & 46 & 41 & \\
\hline 6 & Nama Penyuluh & Demsy Ngantung, SP & Maksy Tangkawarow, SST & $\begin{array}{l}\text { Meiske Anes, } \\
\text { Amd }\end{array}$ & \\
\hline 7 & Jenis Kelamin: & Laki-laki & Laki-laki & Perempuan & \\
\hline 9 & Pendidikan & S1 & S1 & S1 & \\
\hline 10 & $\begin{array}{l}\text { Frekuensi } \\
\text { Pertemuan Oleh } \\
\text { Penyuluh }\end{array}$ & Setiap Minggu & Satu bulan sekali & 2 minggu sekali & \\
\hline 11 & $\begin{array}{l}\text { Alasan Berdiri } \\
\text { Kelompok }\end{array}$ & $\begin{array}{l}\text { Untuk mensejahterakan } \\
\text { anggota kelompok }\end{array}$ & Untuk mendapatkan bantuan & $\begin{array}{c}\text { Untuk } \\
\text { kesejahteraan } \\
\text { anggota } \\
\text { kelompok }\end{array}$ & \\
\hline 12 & $\begin{array}{l}\text { Penghargaan yang } \\
\text { diperoleh }\end{array}$ & & & $\begin{array}{c}\text { Peringkat ke-2 } \\
\text { Provinsi } \\
\text { Sulawesi Utara } \\
\text { dan Kelompok } \\
\text { Tani Terbaik se- } \\
\text { Kota Tomohon }\end{array}$ & \\
\hline 13 & $\begin{array}{l}\text { Bantuan yang } \\
\text { diperoleh }\end{array}$ & Uang Tunai, Pupuk. & Uang Tunai. & $\begin{array}{l}\text { Sepeda Motor } \\
\text { dan sejumlah } \\
\text { Uang Tunai. }\end{array}$ & \\
\hline
\end{tabular}

\section{KESIMPULAN DAN SARAN}

\section{Kesimpulan}

Dari hasil penelitian yang didapatkan, kelompok tani yang letaknya relative jauh dari BP3K memiliki kelengkapan administrasi yang baik dibandingkan dengan kelompok tani yang letaknya sangat dekat dengan BP3K. Hal itu disebabkan karena kelompok tani yang dekat dengan BP3K mempunyai motivasi hanya untuk mendapatkan bantuan dan kurangnya kerja sama antara sesama pengurus selain itu kurangnya perkunjungan yang diadakan oleh penyuluh pada kelompok tani yang dekat dengan BP3K, sedangan pada kelompok tani yang jauh dari BP3K memiliki motivasi untuk mensejahterakan anggota kelompok tani dengan kerja sama dan manajemen yang baik, juga selalu mendapatkan perhatian dari penyuluh dengan mengadakan perkunjungan secara rutin kepada kelompok tani sehingga berpengaruh terhadap kelengkapan administrasi kelompok tani tersebut. 
1. Untuk kelompok tani :

a) Kelompok Tani Susuripen

Pengurus harus lebih memperhatikan bukubuku kelengkapan administrasi kelompok tani, ada beberapa buku yang tidak ada yaitu

- Administrasi kegiatan (Buku Ekspedisi, Buku Kepemilikan Sarana/Prasarana Anggota, Buku Luas Lahan Garapan, dan Buku Pengurus).

- Administrasi keuangan yang belum diisi lengkap yaitu (Buku Kas), dan buku yang tidak ada yaitu (Buku Iuran Anggota, Buku Tabungan Anggota, Buku Penjualan, Buku Pembelian).

b) Kelompok Tani Rewoh Indah Pengurus harus lebih memperhatikan keaktifan dari anggota, juga seluruh kelengkapan administrasi kegiatan dan keuangan kelompok tani yang tidak ada agar di lengkapi demi kemajuan kegiatan kelompok tani Rewoh Indah.

c) Kelompok Tani Sinambey Mujair

Meskipun kelengkapan administrasi kegiatan dan keuangan mendapat kriteria baik, masih ada beberapa buku yang harus di lengkapi yaitu dalam administrasi kegiatan yang harus diisi dengan lengkap dan benar yaitu (Buku Ekspedisi, Buku Kepemilikan Sarana/prasarana Anggota, dan Buku Luas Lahan Garapan).

2. Untuk penyuluh agar dapat memperhatikan kondisi kelompok tani sesuai dengan tugas dan tanggung jawab sebagai penyuluh dalam upaya meningkatkan kinerja kelompok tani.

3. Untuk pemerintah agar dapat memberikan arahan kepada penyuluh dan kelompok tani untuk dapat mengikuti setiap prosedur atau persyaratan yang berlaku bagi para penyuluh maupun kelompok tani sesuai dengan peraturan pemerintah demi kemajuan pembangunan di bidang pertanian.

\section{DAFTAR PUSTAKA}

Djamali. R. Abdoel 2000. Usahatani.: Penerbit CV. Serajaya. Jakarta

Damima, V. 2001. Dinamika Kelompok Tani Padi Sawah di Kecamatan Tondano Kabupaten Minahasa (Studi Kasus Kelompok Tani di Desa Tataaran 1). Skripsi Fakultas Pertanian. Universitas Sam Ratulangi. Manado.
Departemen Pertanian. 2007. Pedoman Pembinaan Kelembagaan Petani. http://www.deptan.go.id/bpsdm/peraturan/ Permentan\%20273-2007\%20 Lampiran \%201.PDF. (Diakses pada tanggal 16 Juli 2016).

Hendi Haryadi. 2009. Administrasi Perkantoran untuk Manajer \& Staf. Jakarta: Transmedia Pustaka.

Hermanto, 2007. Rancangan Kelembagaan Tani dalam Implementasi Prima Tani di Sumatra Selatan. Jurnal Analisis Kebijakan Pertanian.

Kementrian Pertanian, http://cybex.pertanian.go.id/materipenyulu han (diakses pada tanggal 16 Juli 2016).

Kelsey, LD and Cannon CH. 2001. Cooperative Extension Work. Comstock Publishing Associates. New York.

Mardikanto, T. dkk. 2001. Prosedur Penelitian Penyuluhan Pembangunan. Surakarta: Prima Theresia Pressindo.

Nuryanti dan Swatika. 2011. Peran Kelompok Tani dalam Penerapan Teknologi Pertanian.

Ode. Jurnal Ilmu Pertanian Indonesia Vol 19, No 1 (2014) Publisher: Institut Pertanian Bogor.

Oudejans Jan, H.M, 2006. Perkembangan Pertanian Di Indonesia. UGM Press, Yogyakarta

Peraturan Menteri Pertanian Nomor 82/permentan/OT.140/8/2013

Rahim. 2007. Ekonomi Pertanian. Penebar Swadaya,. Jakarta. Sinar Tani.

Sadikin M., 2001, Pengembangan Sektor Pertanian (Penanganan Komoditi Unggul), UGM Press, Jakarta.

Sumual, Nova. 2015. Kajian Kinerja Penyuluhan Pertanian Di Wilayah Kerja Balai Penyuluh Pertanian, Perikanan dan Kehutanan (BP3K) Kecamatan Amurang Timur. Skripsi Fakultas Pertanian Universitas Sam Ratulangi. Manado.

Suratiyah. 2006. Ilmu Usahatani. Penebar Swadaya. Jakarta. Sutardjo. 1996.

Suswono, 2013. Pedoman Pembinaan Kelompok Tani dan Gabungan Kelompok Tani. Kementrian Pertanian. Jakarta

Suwandi, Achmad. 2006. Administrasi Penyuluhan Pertanian. Universitas Terbuka. Jakarta 